\title{
DOCUMENTATION FOR PRESERVATION: METHODOLOGY AND A GIS DATABASE OF THREE WORLD HERITAGE CITIES IN UZBEKISTAN
}

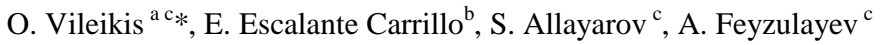 \\ ${ }^{a}$ University of Leuven, Belgium ona.vileikis@kuleuven.be \\ ${ }^{\mathrm{b}}$ Instituto Nacional de Antropología e Historia, Mexico \\ ${ }^{\mathrm{c}}$ UNESCO Office in Tashkent, Uzbekistan
}

Commission II

KEY WORDS: Heritage Documentation, Inventories, GIS, Silk Roads, World Heritage, Historic Cities, Uzbekistan

\begin{abstract}
The historic cities of Uzbekistan are an irreplaceable legacy of the Silk Roads. Currently, Uzbekistan counts with four UNESCO World Heritage Properties, with hundreds of historic monuments and traditional historic houses. However, lack of documentation, systematic monitoring and a digital database, of the historic buildings and dwellings within the historic centers, are threatening the World Heritage properties and delaying the development of a proper management mechanism for the preservation of the heritage and an interwoven city urban development. Unlike the monuments, the traditional historic houses are being demolished without any enforced legal protection, leaving no documentation to understand the city history and its urban fabric as well of way of life, traditions and customs over the past centuries. To fill out this gap, from 2008 to 2015, the Principal Department for Preservation and Utilization of Cultural Objects of the Ministry of Culture and Sports of Uzbekistan with support from the UNESCO Office in Tashkent, and in collaboration with several international and local universities and institutions, carried out a survey of the Historic Centre of Bukhara, Itchan Kala and Samarkand Crossroad of Cultures. The collaborative work along these years have helped to consolidate a methodology and to integrate a GIS database that is currently contributing to the understanding of the outstanding heritage values of these cities as well as to develop preservation and management strategies with a solid base of heritage documentation.
\end{abstract}

\section{INTRODUCTION}

For more than two millennia, from the 2 nd century BC to the 16th century, the Silk Roads was a path of integration, exchange and dialogue between East and West (Elisseeff, 2000). A large number of historic cities are still represented with their outstanding values such as the ones located in Uzbekistan. These heritage values are making them exceptional examples of architecture, both religious and vernacular buildings, such as the legacy of the Islamic religious ensembles and traditional houses; urban design of medieval narrow streets and a system of mahallas (neighborhoods); and close relation with the environment, illustrated with the development of water management systems as an answer to the harsh desert climate (Knobloch, 2001; Krugmeier, 2015). All these features are irreplaceable and continuously vulnerable to the footprint of development, as it happened with the vernacular earthen architecture during Soviet times (Fodde, 2010). Despite the replanning of the urban areas, Soviet researchers (since 1920s) made a considerable contribution into the preservation and study of monuments, ensembles and urban fabric of historic cities (Pisarchik, 1937; Voronina, 1951). However, this cultural heritage has not been systematically and digitally documented in Uzbekistan. The documentation is on paper, and part of these documents has been irretrievably lost. In particular, this happened when the archive of the Tashkent Research Institute of Restoration was abolished in the 1990s.
Currently, the traditional houses, and thus the urban layout, of the four World Heritage historic centers in Uzbekistan, are exposed to rapid transformation. These changes have been mainly caused by the owners and local authorities looking for better comfort and quality of life. Unfortunately, the lack of guidance from the authorities and awareness of the residents about the procedures of conservation and maintenance of the houses, and insufficient legal protective policies are damaging the fabric and the traditional elements are being lost. As noted by Ford et al. (1999), it is important, then, for the preservation of the historic urban landscape, to identify and record the vernacular buildings of historic value with its setting, in addition to the architectural significance of the building.

This scenario encouraged the national authorities to reconnaissance the historic centers and to develop a systematic documentation with the support of the local and international community. Therefore, from 2008 to 2015, the Principal Department for Preservation and Utilization of Cultural Objects of the Ministry of Culture of the Republic of Uzbekistan (Board of Monuments), with support of the UNESCO Office in Tashkent, conducted seven field campaigns to document the monuments and dwellings of the listed World Heritage cities of Bukhara, Itchan Kala and Samarkand. The surveys were conducted in collaboration with several national and international universities and institutions, and a large number of trained volunteers. It was foreseen that the information collected could aid to understand the state of integrity and authenticity of the historic buildings, to identify the location of the traditional

\footnotetext{
* Corresponding author
} 
houses, to evaluate the validity of the World Heritage boundaries and buffer zones, and to serve as baseline information for the development of the Management Plans of the historic cities.

This contribution focuses on the survey of dwellings in the Silk Roads cities of Bukhara, Samarkand and Itchan Kala, and the mapping of boundaries and buffer zones of the World Heritage properties. Specifically, it describes the consolidated documentation strategy and methodology for conducting the survey, and the use of Geographic Information Systems (GIS) as a tool to storage, analyze and manage the large datasets collected.

\subsection{The Traditional Uzbek Houses}

The traditional houses in the different regions of Uzbekistan differ in composition, arrangement of rooms, decoration and other accessories. This study takes as an example the Bukharian vernacular house as described below.

The houses consist of 1-2 stories with a basement for storage of products or livestock. They have clear summer premises facing the north, and winter rooms facing the south. Depending on the welfare of the owner, a number of rooms were added varying in orientation - east or west. The same division is followed in the outer courtyard (see Figure 1).

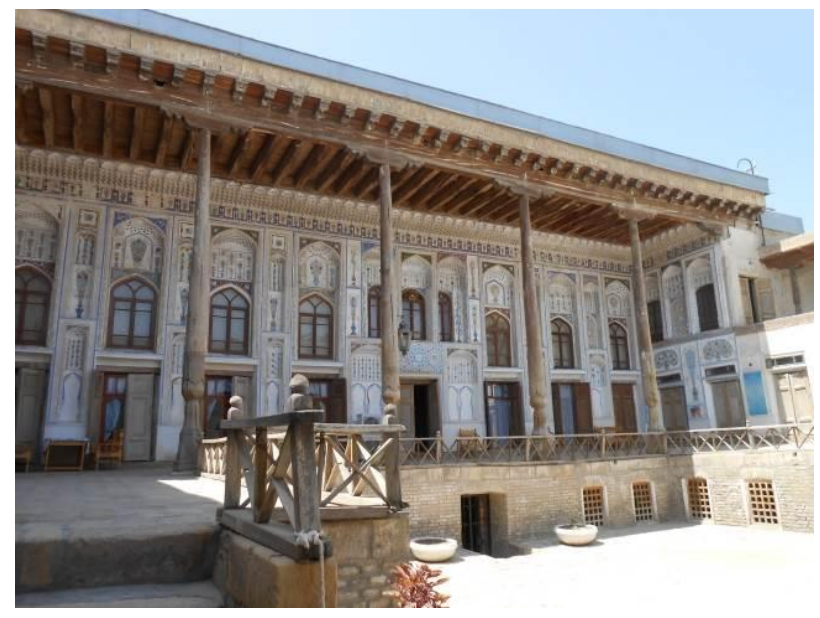

Figure 1. The Jewish House in Bukhara. Traditional Bukharian house with nim-ayvan. (C) UNESCO field survey project (2013)

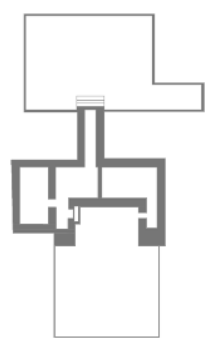

Basement Floor Plan
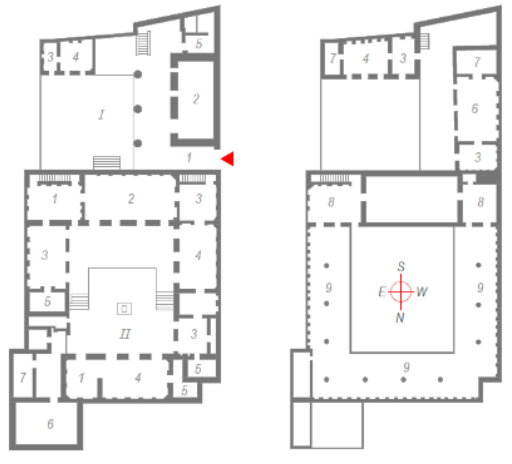

First Floor Plan

Figure 2. Base plan of Abdullah-bek house in Bukhara. Built by Shirin Muradov. Source: authors based on Voronina (1951)
There is a rich decorated ayvan, a terrace with a flat roof supported by multi-columns or pillars, sometimes next to the summer room. Middle-class dwellings often do not have ayvans, only utility awnings. However, low and narrow ayvans can be arranged on the roof of the rooms. This allowed the roof to be used during the day and during the night for sleeping. The rooms are arranged in the interior court yard around a small terrace. Figure 2 shows an example of the distribution of a traditional Bukharian house.

For centuries, the basic building technique was paksha, rammed earth, built with clay and bricks, raw or burnt (Fodde, 2009). Both materials adapt to the differences in temperature throughout the year $\left(-30^{\circ} \mathrm{C}\right.$ to more than $\left.+40^{\circ} \mathrm{C}\right)$ and create a perfect interior microclimate. As Figure 3 illustrates, the houses were mostly closed to the exterior with a latticed opening, tobadon, normally located above the window or door opening.

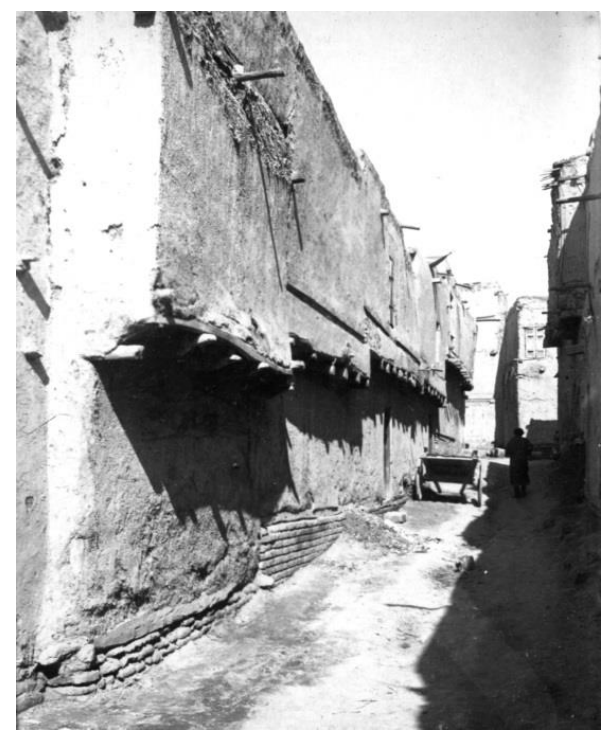

Figure 3. Street façade of traditional Bukharian houses. (c) Courtesy of Zoirsho Klychev

In the interior, the ayvan adjacent to the premises leads to the mekhmonkhona, living and ceremonial summer room. As illustrated in Figure 4, it is a two-story space, often combined with one or two mezzanines, arranged above the entrance hall. The mekhmonkhona is the most beautiful and well-decorated room to receive guests.

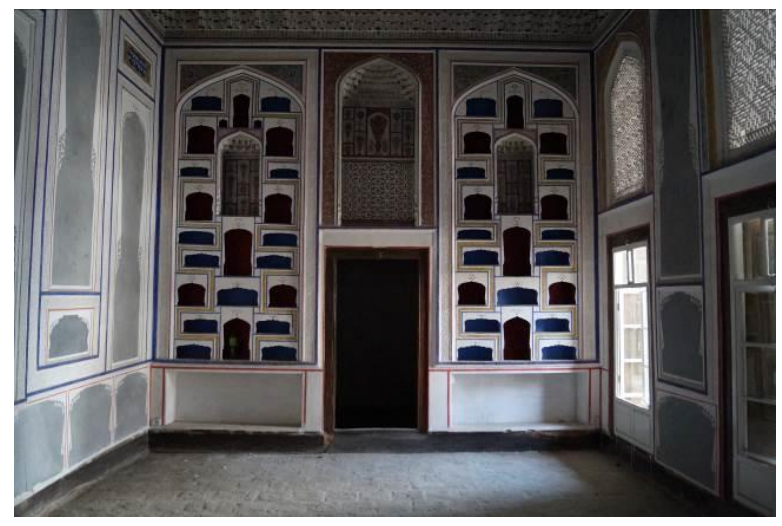

Figure 4. Mekhmonkhona in Bukhara. (C) UNESCO Field Survey project (2013) 
The interior design is characterized by a ceiling with decorated carved and painted roof beams; lush stalactite cornices, carved painted panels and bright painting (see Figure 5). However, in the past, decoration of the walls was much stricter, limited to white plaster carvings and profiling.

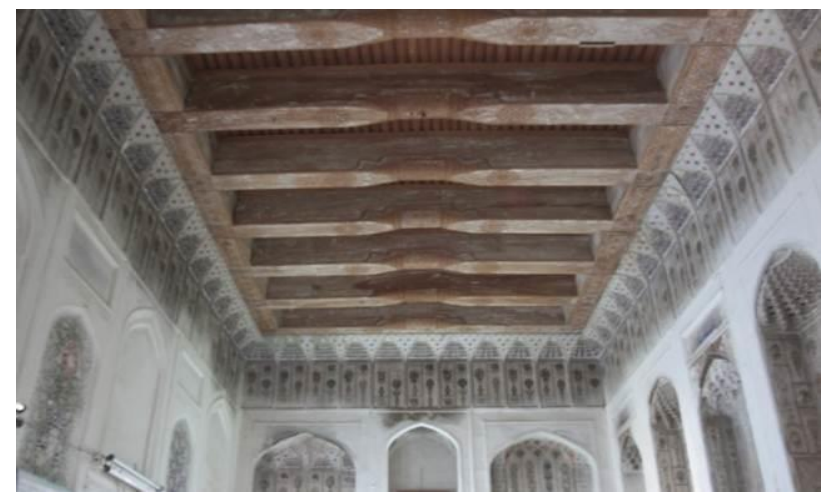

Figure 5. Ceiling beams in a traditional Bukharian house. (c) UNESCO Field survey project (2013)

The central niche of the mekhmonkhona's end wall imitated a mekhrab, praying niche in a mosque. The spaces between niches were often decorated with skillfully carved gypsum planks; the depth of the niches were usually stained with bright, saturated colors - red, blue, yellow. This colorful effect enriched and enlivened the interior.

\section{A STRATEGY FOR SURVEYING THE [TRADITIONAL] UZBEK DWELLINGS}

The activities in the Historic Centre of Bukhara were carried out between 2008 and 2013. The data was gathered during five field campaigns in summer (see Figure 6). In 2015, after this successful experience, a similar survey with international cooperation was carried out in Itchan Kala and Samarkand. These experiences built a consolidated methodology for the documentation of the traditional historic houses in Uzbekistan.

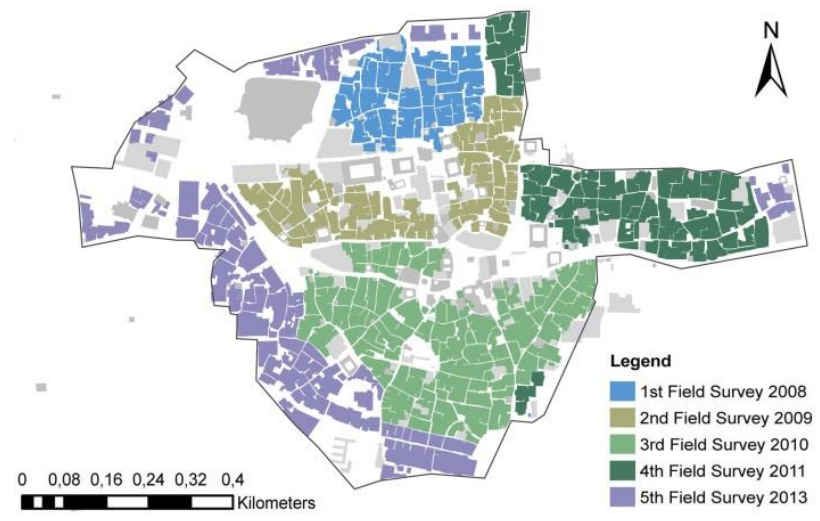

Figure 6. Survey phases in Bukhara (2008-2013). ( ) UNESCO Field survey project (2013)

Information was recorded at a reconnaissance level. The equipment and survey forms were provided by the UNESCO Office in Tashkent and the Board of Monuments (BoM). During the first day of each campaign an introduction was given to the participants about the elements of the traditional houses, together with an explanation about the forms and concepts. Due to the high temperatures in summer, field work took place usually during the mornings or later afternoons, and office work, digitizing all information, in the afternoon and evenings.

\subsection{Teams and Techniques}

2.1.1 Teams: The teams were multi-disciplinary, e.g. architects, historians, archaeologists, social scientists; multicultural and interinstitutional. Each team had a minimum of two local volunteers to carry out the interviews, considering the language barrier for the international participants.

Survey techniques and equipment: All teams were equipped with basic survey tools, such as tapes or laser distant measurers (disto) and digital cameras. Main measurements were taken of the facades, the width of the roads and the interior of the houses. The cameras were used to take interior and exterior photos of the houses. Cameras varied from a typical pocket/compact-size Canon Power-shot to reflex cameras D5000 and D3000 from Nikon that also used lenses such as Nikkor Fish-eye 10.5 or Nikkor $18-200 \mathrm{~mm}$. A tripod with panoramic header was always available to take details of damages or general conditions of the houses as well as panorama and $360^{\circ}$ photography (see Figure 7).

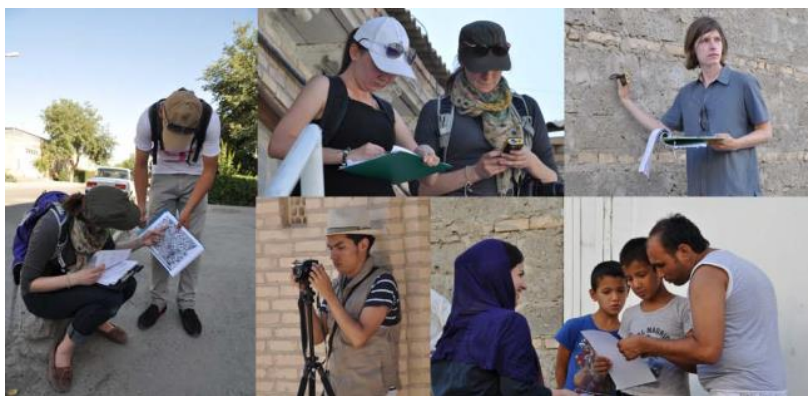

Figure 7. Surveyors during field work in Bukhara. () UNESCO Field survey project (2013)

\subsection{Processing information collected: building a GIS Database}

GIS was selected as the digital documentation tool to build the database. GIS has been recognized as an ideal tool to store, analyze and manage large datasets (Longley et al., 2011). The advantage of using a GIS database was to consolidate an inventory with a variety of data formats from available sources, such as written, graphical, cartographical, first hand observation and documentary material, similar to what have been achieved in the documentation of vernacular architecture in the UK (Ford et al., 1999).

For each one of the three historic cities, a GIS database was created, allowing the relevant authorities to manage the information separately. It contained listed monuments, surveyed dwellings and World Heritage boundaries and buffer zones. First, each group added the information to an Excel sheet including all the fields of the questionnaires. This tool was selected as not all of the participants had GIS skills. Then, ESRI ArcMap 9.3 was used to map the houses and to link the excel database with the location of the houses. The final product was 
delivered as both, ESRI ArcMap 9.3 with an access database, and QGIS with excel database, as for the later no license fee is required.

As no updated cadastral maps were available, Google maps were used as a background layer to prepare the GIS map of all surveyed dwellings, as shown in Figure 8. In the case of Bukhara and Samarkand, a high resolution Quick Bird satellite image was acquired and used as a background layer for the GIS database. The database structure was based on the survey forms and allowed the superposition of layers, an easier visualization and a large number of queries.

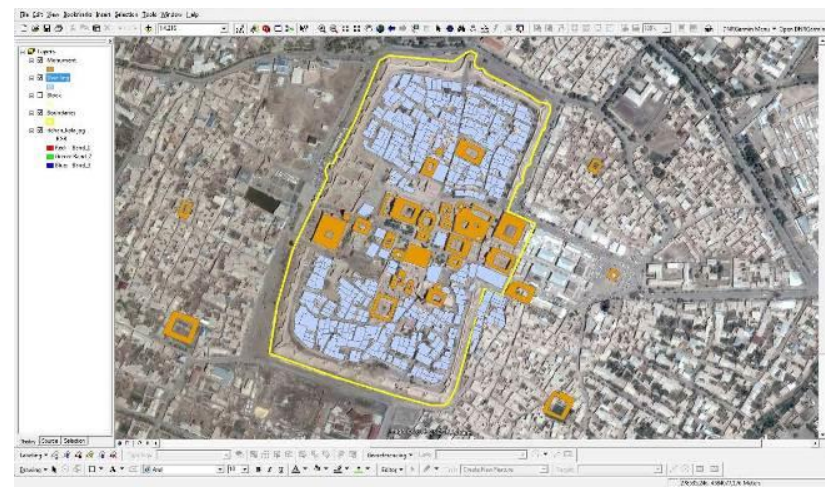

Figure 8. Itchan Kala GIS in ArcGIS 9.3. Depicting monuments, city blocks, surveyed dwellings and World Heritage boundaries. Source: Background layers (c) Google maps (2015) and data (C UNESCO Field survey project (2015)

For data analysis, AutoCAD 2014 and Sketchup software were used to draw floor plans of the houses, PTGui photo stitching to create panoramas, and Microsoft Office Excel 2012, ESRI ArcMap 9.3 and QGIS 2.10 to transfer the information recorded in the assessment forms into a digital format. Additionally, folders were created containing scanned questionnaires; excel database, corresponding photos, and floor plan drawings in PDF, and AutoCAD 2014 or Sketchup files.

The photos were renamed following a file protocol (see Figure 9) and linked to each house in the database.

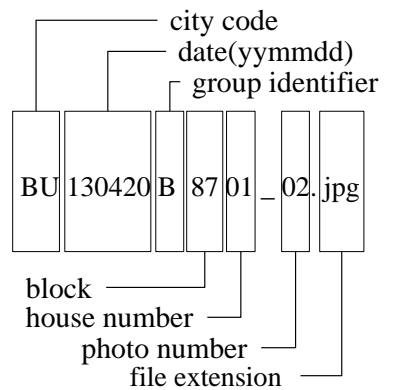

Figure 9. File protocol. @ UNESCO Field survey project

\subsection{Dwellings Assessment}

Each group was provided with assessment forms, guidelines, general map, key maps by block, and an official letter of the BoM to access the dwellings (see Figure 10). Different to
Bukhara and Itchan Kala, in Samarkand just traditional houses were surveyed.

The forms were comprised of two worksheets: the condition survey form and the Nara Grid (Van Balen, 2008) form for the values assessment of the traditional houses. The assessment form included not just general and physical information of the property, but also social aspects of the residents.

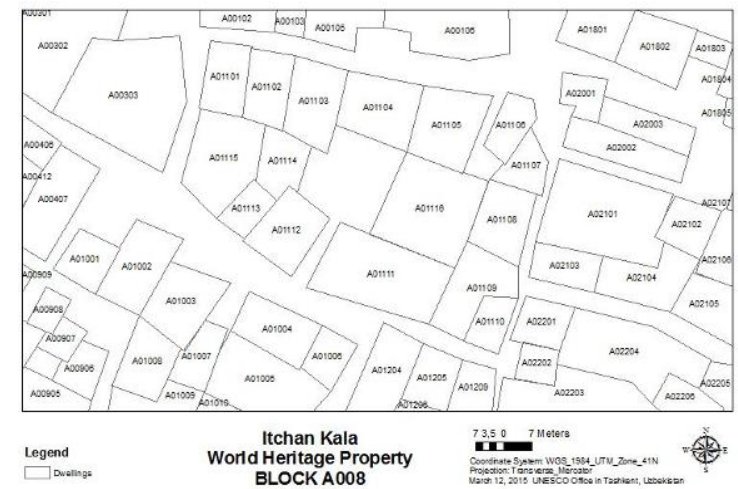

Figure 10. Example of key map provided for Itchan Kala, with the distribution of the dwellings, ID blocks and ID number.

(c) UNESCO Field survey project (2015)

The guidelines on how to carry out the assessments and document the data follow internationally recognized standards and charters (Council of Europe, 2009; Australia, ICOMOS 2013). Due to the language barrier, the guidelines also included a trilingual (English, Russian, Uzbek) visual glossary, damage atlas and list of threats tailored-made for the Silk Roads (Vileikis et al., 2014). In the case of Samarkand photos of some traditional houses of 2010 and 2012 were provided by the Inspection. In 2015, based on the Bukhara experience, the assessment form was improved. The changes included additional socio-economic data such as householder age, number of people (discriminated by gender and age) and number of people working, as well as information about maintenance. It allowed delivering more precise information for further socio-economic and monitoring analyses. All information was translated in both Russian and Uzbek.

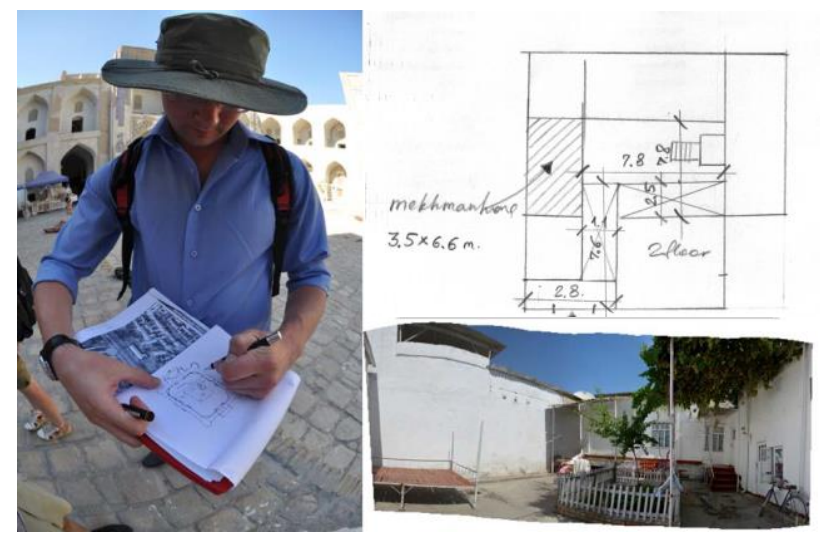

Figure 11. Survey during field work in Bukhara. (C) UNESCO Field survey project (2013) 


\subsection{The GIS database and the Survey Control}

In Bukhara, 4063 dwellings and 180 historic buildings were surveyed within the historic center. The survey helped to identify traditional houses with high heritage value that were not on the national protected heritage list. It also revealed that the boundaries and buffer zones were not properly delineated. These limits did not have any legal value, and the historic center was not acknowledged by the stakeholders as a city as a whole (including the traditional houses) within its boundaries, but just as single monuments within a city. Boundaries and buffer zones will be legalized by decree based on the Outstanding Universal Value and in agreement with all stakeholders.
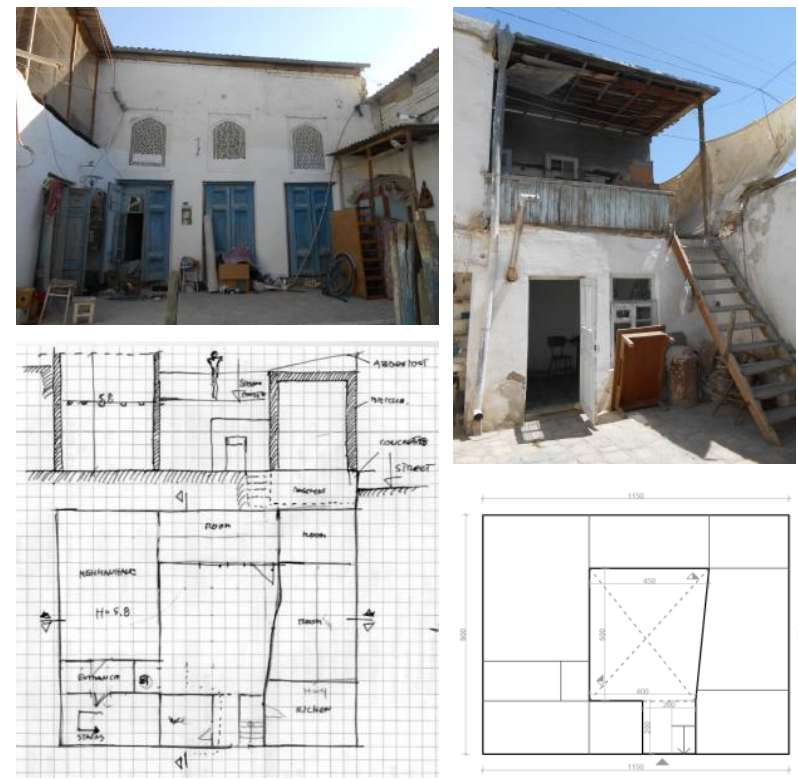

Figure 12. Field notes and floor plan in AutoCAD. Survey of traditional houses in Bukhara. (C) UNESCO Field survey project (2013)

Following the same methodology of Bukhara, in Itchan Kala a total of 381 dwellings were documented, of which 297 were fully surveyed, this means complete filled out survey form and interior photographs. Different to the other surveys, in Samarkand, only the traditional houses were surveyed. The task was to review a list of 71 traditional houses provided by the Inspection of Samarkand and locate them in the GIS.

Previously in 2010 and 2012, 50 of these traditional houses were identified and registered by the local authorities under national protection. From this list of 71 traditional houses, six were already crossed out by the inspection, one was not found during the survey (unknown location), eight were abandoned, two houses with different ID were one, and one house was divided into three plots (having now three different owners). The final GIS database of Samarkand comprises a total of 67 traditional houses, of which 49 were fully surveyed (survey form and photographs). The GIS database gave precise location of the traditional houses surveyed. Information of the visual glossaries, previously developed in Bukhara, were updated and tailored made to Samarkand and its traditional houses. The limited number of houses allowed a more a detailed values assessment by filling out a Nara grid for each house.
After the survey assessments, the information collected was added to the database. During this task, information was crosschecked with the photos and drawings taken in the field. The measurements were adjusted in AutoCAD, but they were not further verified. Their aim was not replace a cadastral plan, but to show the layout plan with the uses and distribution of the houses. The good resolution of the satellite images helped to verify the land plot and composition of each house unit. The traditional houses identified with high heritage value were marked as a priority to be revisited by the heritage authorities, and a thorough assessment should be scheduled.

The completed GIS database is now managed by the Inspections of Bukhara, Samarkand and Khorezm. However, there is no, online, centralized shared system giving access to the other stakeholders.

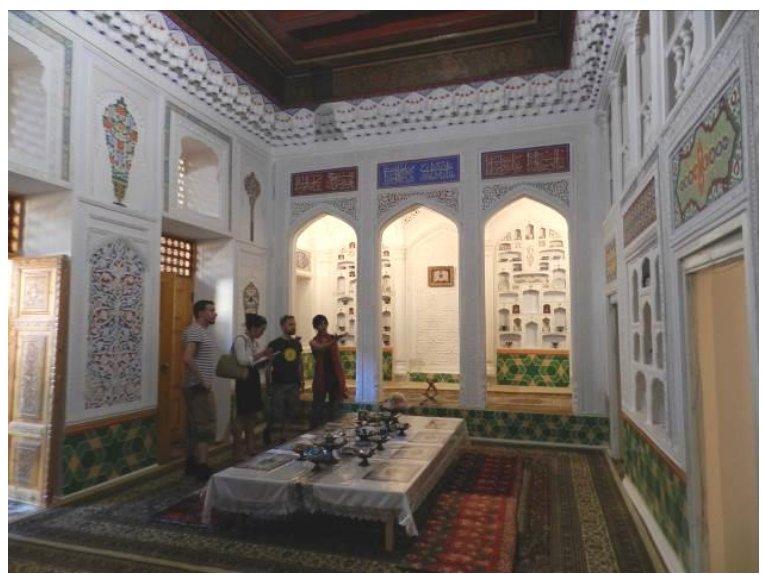

Figure 13. First hand observation inside a traditional house with high heritage value in Samarkand. (C) UNESCO Field survey project (2015)

\subsection{Mapping Boundaries and Buffer Zones}

In the three World Heritage cities, the precise delineation of the World Heritage boundaries was verified, and the buffer zones were defined, or slightly modified in the case of Bukhara and Samarkand. This information was integrated into the GIS database.

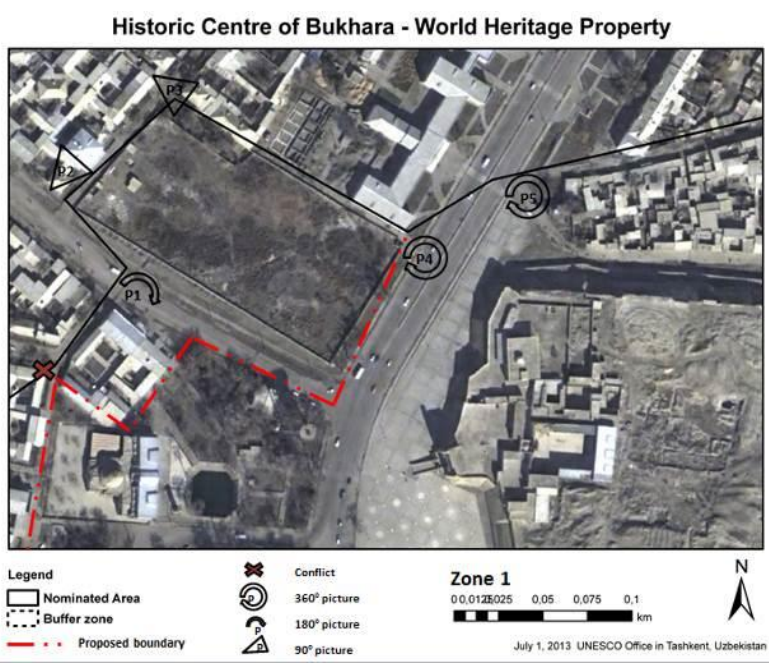

Figure 14. Example of boundaries verification in Bukhara. (C) UNESCO Field survey project (2013) 
The methodology for the assessment of the boundaries and buffer zones was drawn on the Risk Management project in Petra, Jordan (Paolini et al., 2012). As illustrated in Figure 15, the boundaries were divided in sections and panorama photos were taken to register them and their surroundings. Different to the Petra experience, within the urban context the boundaries were not difficult to find and to mark on the maps.

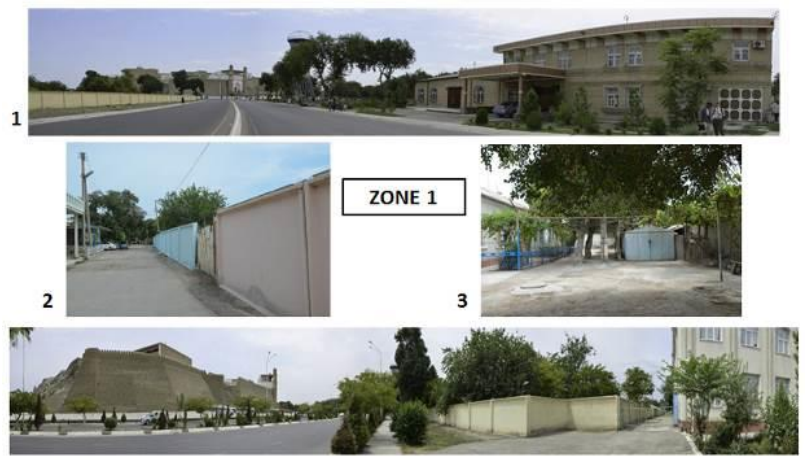

Figure 15. Example of photos of boundaries verification in Bukhara () UNESCO Field survey project (2013)

As shown in Figure 16, the buffer zones were surveyed by zones. This assessment aimed to identify the land use, height of buildings, green and open areas, and the important architectural assets that are related to the historic center core area.
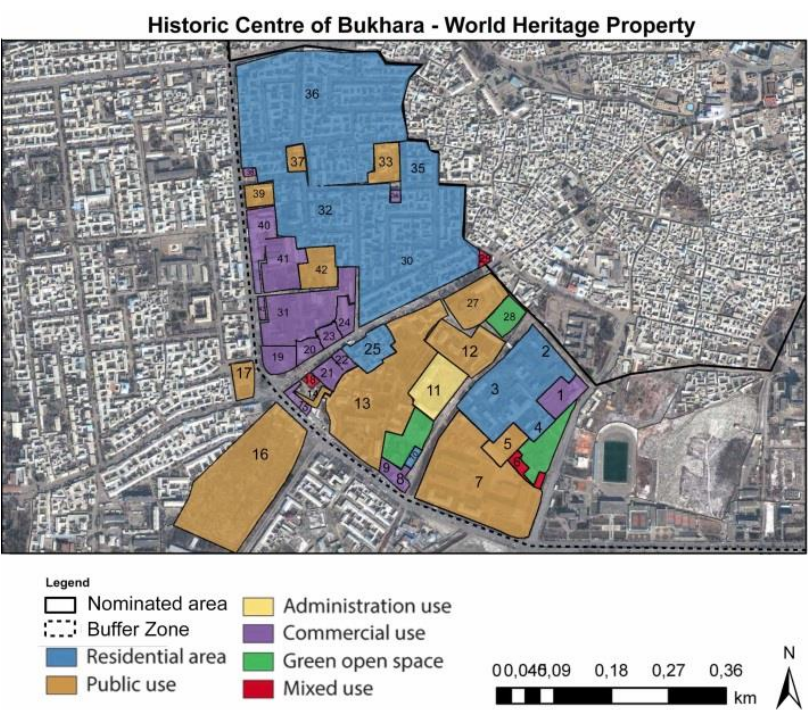

Figure 16. Zonification of the Buffer Zone around the World Heritage property of Bukhara. (C) UNESCO Field survey project (2013)

All information mapped was added to the GIS database and results were discussed with the BoM. The evidence gave the authorities bases to take informed decisions. The study brought a minor modification of the boundaries and buffer zones to the Historic Centre of Bukhara and delineation of buffer zones in Itchan Kala. The first one has been already approved by the World Heritage Committee and its legal integration into the Master Plan of the city is urgently recommended (see WH Committee Decision 40 COM.B.41).

\subsection{Thematic Maps}

The database linked the information of the dwellings and monuments surveyed with the field survey questionnaires photographs and location, allowing the analysis of the georeferenced data previously documented. The use of a GIS allowed complex queries of the data sets to be undertaken, providing opportunities for visual analysis at different levels and approaches. Values and physical condition thematic maps were developed for the historic centers of Bukhara, Samarkand and Itchan Kala.

Thematic maps were created illustrating changes in the values of the traditional houses, for example due to the change of use or building materials. With the adequate data assessment, these thematic maps also showed the current physical condition of the surveyed traditional houses, including infrastructure and the visualization of damages and identification of threats. With advanced querying, the GIS could also link information, e.g. show houses with high heritage value in very bad condition. This information is currently helping the local authorities to prioritize future interventions and management decisions (Vileikis and Allayarov, 2015).

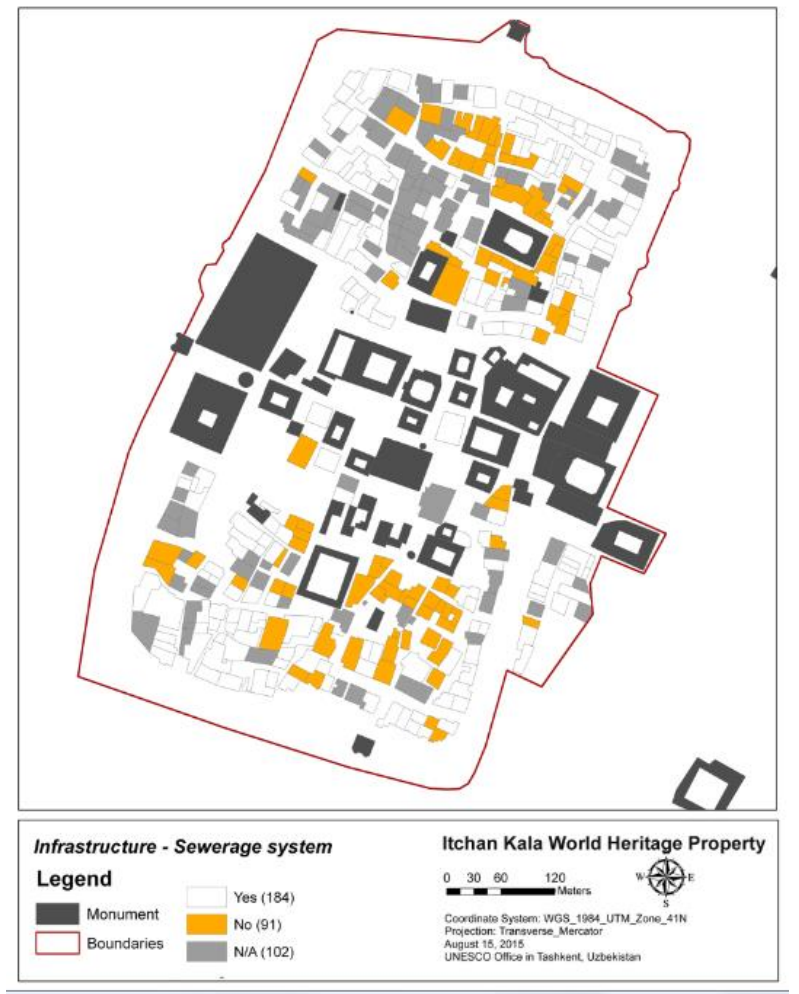

Figure 17. Thematic map showing availability of sewage system in Itchan Kala. (C) UNESCO Field survey project (2015)

The thematic maps illustrated the importance of the interconnection of several types of information for the management of the Uzbek urban heritage. They took into action techniques of mapping and integrated them into the historic environment, economy, society and culture. As Ripp and Rodwell (2015) noted, approaching preservation and management of historic cities through the geography of urban heritage allows tracking continuous processes of change. For that a dynamic GIS database was crucial for monitoring and 
management processes on the Uzbek context in the XXI century.

\subsection{Outreach Activities}

In 2015, results of the survey were presented to the stakeholders of Bukhara together with the Senate of the Republic of Uzbekistan. The outcome of this meeting was the approval of Decree No. 200 by the Cabinet of Ministers (Republic of Uzbekistan, 2014) and an Action Plan, including the appointment of a national Focal Point for UNESCO World Heritage, and the creation of a new department in restoration at the Tashkent Architectural and Construction Institute (TACI) and Samarkand State Architectural and Construction Institute (SamGASI).

During the summer of 2013, a leaflet about Bukhara as World Heritage was developed with the participation of the children living in the historic center (see Figure 18). The activity served to express and create awareness among the young generations (Vileikis and Allayarov, 2014).

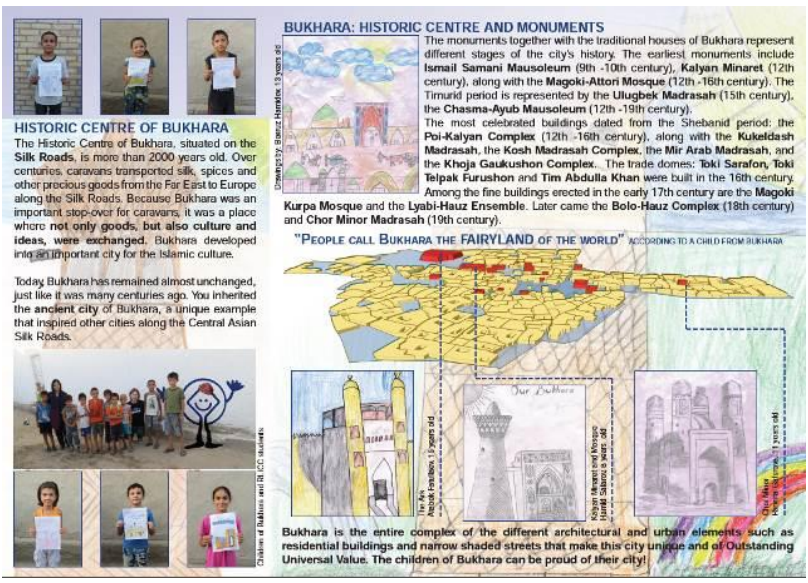

Figure 18. Children's leaflet of the Historic Centre of Bukhara (C)UNESCO (2013)

Additionally, in 2015, the information was also presented and analyzed during the consultation meetings for the Management and Strategic Plans of the historic cities. The stakeholders were provided with relevant facts for the strategic planning of the city. The findings included identification of conservation issues as a means to develop conservation and monitoring schemes; identification of sustainable human use and benefits with the property and its buffer zone; collection of legislation, decrees and local programs for the definition of management objectives; identification of weaknesses and gaps in institutional and economic frameworks; and development of monitoring, analyzing and reporting based on the GIS database.

\section{CONCLUSION AND OUTLOOK}

The GIS database had a crucial role on the planning process of the city, heritage and other authorities working in the historic centers. The information documented and integrated on this database responds to an identified lack of baseline information that is needed for the adequate justification of preservation and management strategies. The GIS database of the past field campaigns in Bukhara, Samarkand and Itchan Kala is helping the local authorities and heritage experts in the assessment of changes to identify the effectiveness of the management strategies, and thus take better and informed decisions.

The methodology for the documentation of the traditional houses in historic cities of Uzbekistan is an example of building up a GIS database for documentation with a 'participative' approach of the community and leading to a preventive conservation. Its adequate selection was essential for the conservation, preservation and management of the World Heritage properties. The final result, a well-integrated GIS database, represents the consolidation of a monitoring process and the baseline for the decision making process.

The successful GIS database obtained from the field campaigns in the three Uzbek world heritage cities is the result of selecting a suitable methodology for documentation to integrate the data. One of the main accomplishments of this database has been the capacity to illustrate contextual relationships between the data. It has been able to consolidate a documentation methodology to accommodate and integrate both spatial and descriptive data. Further GIS training to the local authorities has been foreseen as part of the action plan of the Management Plans as well as the development of a strategy for updating and adding new information to the inventory.

It is relevant to highlight the large extent of the area covered with around 4500 dwellings surveyed. This survey revealed not just the physical condition of the buildings, but a better understanding of the heritage and economic values of the historic centers, an accurate mapping of boundaries and buffer zones. It also reviewed the legislation related to cultural heritage protection and gave recommendations for its improvement. The project also promoted heritage awareness among the local community. This study did not aim to replace an accurate detailed architectural survey of the vernacular architecture in Uzbekistan. This is a future step to be taken.

The GIS database of the historic cities in Uzbekistan has been crucial for the development of management strategies within the local authorities. It will enhance the valorization and dissemination of cultural heritage within Uzbek and international policies for the adequate preservation of an important segment of the Silk Roads. This paper is an example of innovative heritage documentation methodology and international long cooperation as a strategy for the implementation of the 1972 World Heritage Convention.

\section{ACKNOWLEDGEMENTS}

This project was implemented thanks to the UNESCO Office in Tashkent in close cooperation with the national partners. This includes the Board of Monuments, Ministry of Culture of the Republic Uzbekistan and its Inspections in Bukhara, Khorezm and Samarkand, the UNESCO Chair in the Preservation and Management of Historic Centres, SamGASI, TACI, Urgench State University (USU), as well as the local authorities of each city who participated and provided all kind of support.

Special acknowledgements are given to international institutions and experts that promoted the project and gave advice throughout these years. In particular, the Raymond Lemaire International Centre for Conservation - University of Leuven (Belgium), the Institute of Archaeology - University College London (UK), and BTU Cottbus-Senftenberg (Germany). 
The authors thank all volunteers, interns and students for their invaluable contributions during the surveying campaigns and their strong commitment to the successful implementation of the project.

\section{REFERENCES}

Council of Europe, 2009. Guidance on inventory and documentation of the cultural heritage, Strasbourg: Council of Europe Pub.

Elisseeff, V. ed., 2000. The Silk Roads: Highways of Culture and Commerce, New York \& Oxford: Berghahn Books.

Fodde, E. (2009) 'Traditional Earthen Building Techniques in Central Asia', International Journal of Architectural Heritage, 3(2), pp. 145-168. doi: 10.1080/15583050802279081.

Fodde, E. (2010) "Conservation and Conflict in the Central Asian Silk Roads", Journal of Architectural Conservation, 16(1), pp. 75-94. doi: 10.1080/13556207.2010.10785063.

Ford, M., El Kadi, H., and Watson, L. 1999. "The relevance of GIS in the evaluation of vernacular architecture". Journal of Architectural Conservation, 5(3), pp. 64-75.

Republic of Uzbekistan, 2014. Decree No. 200 from 21.07.2014 of the Cabinet of Ministers on Additional Measures to Enhance Protection and Utilization of Tangible Cultural and Archaeological Heritage, Available at: http://www.lex.uz/ [Accessed August 25, 2015].

ICOMOS Australia, 2013. Burra Charter. Available at: http://australia.icomos.org/publications/charters/ [Accessed June 7, 2014].

Knobloch, E., 2001. Monuments of Central Asia: a guide to the archaeology, art and architecture of Turkestan, London \& New York: I.B. Tauris.

Krugmeier, P., 2015. Samarkand's mahallas. History and culture shape living urban form. Unpublished report.

Longley, P.A. et al., 2011. Geographic Information Systems and Science Third., New York, NY: John Wiley \& Sons, Inc.

Pisarchik, A. K. (1937) "Residential House of Bukhara and Khiva." USSR Architecture No.1

Ripp, M. and Rodwell, D. 2015. "The Geography of Urban Heritage". The Historic Environment: Policy \& Practice, 6(3), pp. 240-276.

Van Balen, K., 2008. The Nara Grid: An Evaluation Scheme Based on the Nara Document on Authenticity. APT Bulletin, 39(2/3), pp.39-45.

Veldpaus, L., et al., 2013. "Urban heritage: putting the past into the future". The Historic Environment: Policy \& Practice, 4(1), pp. 3-18.

Vileikis, O. et al., 2014. The Silk Roads Cultural Heritage Resource Information System: For World Heritage Monitoring and Preservation. International Journal of Heritage in the Digital Era, 3(2), pp.375-392.
Vileikis, O. and Allayarov, S. 2014. Strengthening the role of community in the protection and management of the Historic Centre of Bukhara. In: The Right to [World] Heritage. Conference Proceedings, Cottbus-Senftenberg: IAWHP, pp. 207-218.

Vileikis, O. and Allayarov, S. 2015. Enhancement of the implementation of the World Heritage Convention through strengthening the protection and management mechanism in the historic centre of Bukhara. In: Revisiting Kathmandu. Safeguarding Living Urban Heritage. International Symposium Kathmandu Valley, 25-29 November 2013. UNESCO Office in Kathmandu.

Voronina, V. (1951) Folk Traditions of Uzbek Architecture. Moscow: State Architecture and Urban Planning Publishing House, 